\title{
Students' Characteristic Analysis in the effort of Applying Total Quality Management (TQM) in Learning Process
}

\author{
Wawan Purwanto, Bahrul Amin, Nuzul Hidayat, Erzeddin Alwi \\ Automotive Engineering Department \\ Universitas Negeri Padang \\ Padang, Indonesia \\ wawan5527@ft.unp.ac.id
}

\begin{abstract}
Learning management plays an essential role in creating an atmosphere of learning in improving the graduates' competency. Total quality management (TQM) is a management system that can be applied in a learning process. The purpose of the paper is to describe the initial situation of the student, than to design a TQM appropriately applied to the course of Ototronic technology in the Department of Automotive, Engineering Faculty at the Universitas Negeri Padang. The research method used was snowball research with observation technique. The data processing analysis were described using presentation technique. Moreover, triangulation system was the technique of guaranteeing its validity method. The result showed that the readiness of students in TQM implementation was better, while the process for TQM implementation still required a lot of preparation, especially in the document of learning plan.
\end{abstract}

Keywords-characteristic, total quality management, student, education system, learning process

\section{INTRODUCTION}

The modern learning management systems are the systems that can accommodate an effective, efficient and directed management process on a measurable goal [4]. Furthermore, the process of applying learning management must be clearly described. Therefore, it can guide teachers in implementing the learning process. TQM, as a management process, has been widely applied in the industrial sector, then the system improvement in the production process [5], improves the management system [6], as well as to increase its company profit [7].

In addition to being implemented in the company sector, TQM has been transformed for management in the education system, especially in the learning process [8]. The output is students' satisfaction and increased competence. [9] have reviewed TQM on quality sufficiency, the result of the total quality practice applied was very effective in dealing with customer satisfaction especially in the provision of educational facilities, supporting the students' self confidence and reviewing the activity as a whole. Furthermore, Srima et al
[10] has developed TQM supervision on basic for education institutions as a model in supervisory development. Srima et al [10] developed a quality management information system, as a model in best schools practice. Crawford and Shutler [11] described the problem and issues of TQM in teachers in the classroom, its estuary is to produce good examination results. Crawford and Shutler [11] developed the first assumption that through TQM, the process of quality improvement may produce quality production with "zero defect". The next assumption is the never-ending cycle of improvement in a production system. In this educational context, it implies the improvement of quality instruction as an effort to embed the character of the students of critics, the thinkers are crucial in facing the rapidly changing rate of technological change. Furthermore, TQM can be used as a means to increase the attention, care, and excellent service of school personnel to students as customers [2, 3].

In the process, the application of TQM should be based on systems that have been developed by educational institutions. The process should be followed by a preliminary study, especially on the characteristics of students, previous management, and administrative systems that have been applied [11]. Furthermore, this research is a basic research, especially on recognizing and analyzing the characteristic of students who are studying in automotive engineering department, Engineering Faculty, Universitas Negeri Padang, especially D3 students who learn otortonic. This characteristic is more focused on students' activity during learning process, especially on positive activity and negative activity. The results of this study on the characteristics of the student will be used as guidance in compiling TQM as an effort in developing students' characteristics in the ototronic course.

In the industry sector, TQM is defined as a philosophical management focused on people and work processes, the result is the customer satisfaction and improving organizational performance in the industry. Fig 1 shows that a TQM process starts from raw material that will be processed into a product. 


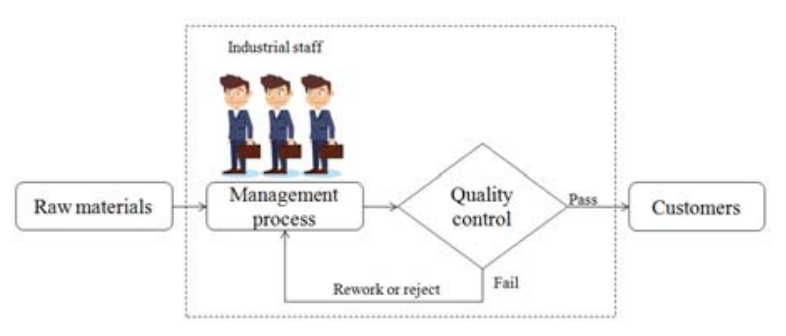

Fig. 1. TQM process in industrial sector

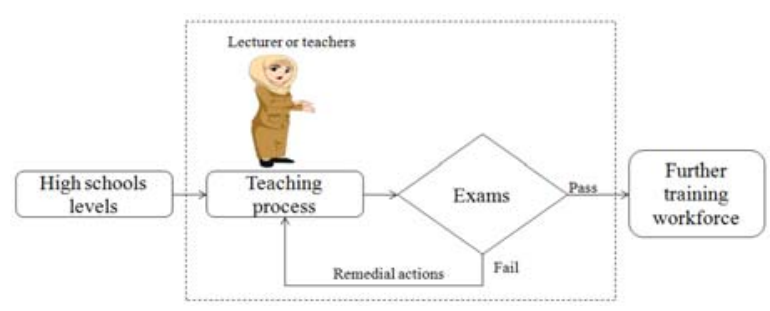

Fig. 2. TQM process in education sector

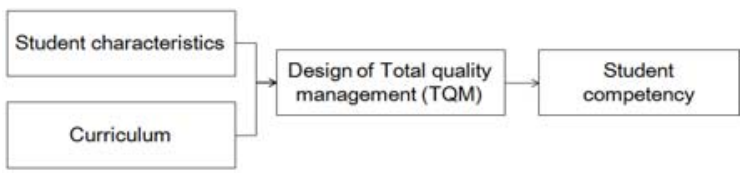

Fig. 3. TQM process in education application

The result of the manufacture of the product will be applied in the quality control, if the result is good then it can be sold to the customer, if the result is bad then it will be improved in the management process. Crosby [1] explained the quality control system can affect the quality of product. While the TQM process is planning and working to reduce the occurrence of defective products. If the defective product approaches "zero defect", it means that the production management system has approached the better result [1].

As a result, the overall cost of production may possibly increase, in return, higher prices needed to create high-quality products. In this regard, Crosby [1] suggested to manufacturers to implement a strategy that manufacturers not only focus on product quality, but also more focused on the quality of production process, so manufacturers will produce best quality products. Relating to each component of a system with the name "total" will be found from the root of the problem and then repaired from the root of the problem in an effort to strengthen the fundamentals of the process that will eventually produce products with zero defects.

TQM is based on "Sustainable Improvement". You shall revise all your processes and make big question on how they can be better and faster, you shall seek for sustainable improvement. Performing team working and collecting the suggestions of staff are necessary for this.
Comparisons and measurements are needed. You shall determine metrics for each process and compare their improvement with "the best of World" and "the best of Market”.

Every organization shall necessarily create information from past achievements and experiences and use the information to tend for the better future. Managers undertake significant roles in using these information. In modern World, where there is a great deal of competition, not ordinary managers but leaders making organizations distinct and successful are needed.

The most important role of the top manager in the transfer to TQM is as a reminder that quality can be achieved through the efforts of everybody from bottom level to top level. If quality practices are meant to give significant results in the long-run, they shall be guided and supported by the top manager at every stage. The top manager shall be a model, create training context, organize, support, encourage quality improvement groups and participate in quality improvement studies in general. Statements of managers shall not conflict their actions in order to have a positive influence on subordinates. Changes of attitude in quality shall be reflected on everybody, from top management to the bottom level management or worker units just like a water flush cleaning the former and bad habits. The important point here is to deliver the messages of top management to the very bottom level without skipping any level and to ensure that medium and bottom level managers in particular adopt the message of the concerning people.

In the application of management systems in the educational process, the first step that must be done was to analyze the input of students coming from various discipline. Its purpose is to determine the management on TQM in accordance with the students' needs. If this analysis is incomplete, then the process of applying the lessons in TQM will experience constraints affecting the length of preparation time, application and adjustment to the method applied. Figure 2 describes the process of applying TQM in schools.

All education experts have pointed that the education is the most important factor to obtain social and economic development of the country. If we take into other components account, except for the students' psychomotor characteristic, the teacher undoubtedly has the major role on students' academic success in education. According to the research, $50 \%$ of students' academic success comes from genetic characteristic while the $30 \%$ from teachers' quality. The remaining $20 \%$ is related to other factors, and education technology has only $6 \%$ share. These research showed us the main investment area is the teacher to have better academic success from education. If we want to have good result from education, first of all, we must provide good curriculum and proper educational environment for the teacher. All of these point out the education faculties.

The importance of education faculties has been increasing day by day because of the need of qualified teachers and the number of trained teachers for new areas of expertise. But, there are some deficiencies to provide better 
educational environment, such as financial limitations, insufficient faculty members, and insufficient campus facilities. Another important point is to provide a chance of employment for all candidates to encourage them to become a teacher.

If the process of applying the lesson has been completed, then the students will be given a quality control before studying the new topic or stepping on the latest subheading. Students who do not pass the exam, should be assisted to repeat the material with a particular treatment with consideration from the teacher. After the deadline is determined then the students can repeat the previously given test. In the examination process, it can be a similar problem, or a new problem that refers to the learning objectives that have been determined. If a student who has not graduated until two or three times, then the next action will be given. The TQM process in this study assumed that the exam is a part of learning in which its purpose is to increase students' skills to think critically and analytically.

As a consequence, the cost of education increases, Cosby [1] provided a strategy focusing not only on students' exam results but more on the quality of the learning process in educating students. Taking into account the total quality, an important teacher finds the cause of the student not passing the exam for sub-material upgrading. Thus the learning process will result in the students passing automatically with a high level of knowledge. Generally, the process of the TQM is shown in Fig 3.

Total Quality Management is democracy. Everybody shall Express their views freely and join management and decisiontaking process somehow. Suggestions of the staff shall be taken, valued and awarded. Communication is a must in Total Quality Management. You shall ensure a twoway and healthy communication with your staff. When all staff knew the vision and mission of your organization, there was synergy to attain objectives. Simple organization structure shall be used, the hierarchy shall be eliminated and open-door policies shall be adopted to improve this communication.

\section{METHOD}

This research used snowball research with qualitative data. The main focus of this study was to identify students' characteristics of both positive and negative activities during the learning process. The research data will be taken by in depth observation. The aspect studied were the matters relating to student activities. The research samples were students who take courses autotronic D3 Automotive engineering. Research data were tabulated, then analyzed with the research team. To ensure the validity of data analysis, the triangulation process was performed. The consideration and focus of data retrieval and analysis were completed before conclusion of sthe students characteristics.

\section{RESULT AND DISCUSSION}

The results showed that activities include positive activities such as, coming on time, making reports on the course of the previous work in the last week, bringing practical equipment, taking note of the teachers' explanation, asking questions, answering questions, and responding to friends' opinions. While the negative activity covered the students coming late, not bringing the resume or report from the previous work in the last week, disturbing friends, chatting with friends, unwilling to give answers and not responding to questions from another student.

From the observations, there are $70 \%$ of students coming on time and has prepared reports or resumes from previous meetings well and neatly. Whereas $30 \%$ of students come late with time span of 5 - 20 minutes delay. This disrupted the learning process since the newly arrived students usually requestion the previous topic in a course that they have not heard. While there are only 4 students who actively ask questions and give answers to questions of teachers and other students. The condition was worsen by the existence of students who are indifferent to the learning topic. While the reports they make, based on the results made by friends or cheating.

To apply a good process in learning the teacher explained the importance of working independently without having to interfere with friends, the result was an increase from the number of students who originally came on time was $70 \%$, now increased to $85 \%$. Thus, this process required gradual improvement, so that students in learning do not experience stress and remain focused on learning activity. After the test, students who passed and continue on subsequent learning increased from the first sub topic by 8 students with a score of 75 , increased to 11 at the next teaching topic. In the design process for the TQM process, the data can be considered primarily in designing learning tools, learning methods, and exam questions to be used in measuring student abilities.

\section{CONCLUSION}

TQM method is a management system that performs a thorough and total improvement. The quality improvements planned at TQM are not unexpectedly but must be analyzed by the condition of the students, the curriculum and the learning methods to be undertaken. From the results of the review, there were students who came late at the learning period and some students answered questions from the teacher. While the quality control of the learning process were only 11 successful students to follow the next course topic, while others have to do remedial. This condition became the main focus in learning by TQM method.

\section{REFERENCES}

[1] P. B. Cosby, Quality without tears: the art of hassle-free management", McGraw-Hill, New york, 1984

[2] M.A. Byrnes, "The quality teacher: implementing total quality management in the classroom, Cornesky and Associates Press, FL, 1992.

[3] J.J. Bonstingl, "Schools of Quality: an introduction to total quality management in education, Association for supervision and curriculum development, Alexandria, VA, 1992

[4] H. Ates and G.A. Baskan, "The precautions to be taken on the faculties of education to improve teacher quality and to increase employment opportunity", Procedia - Social and Behavioral Sciences, vol. 141, pp $861-866,2014$ 
[5] Z.S. Kahreh, A. Shirmohammadi, and M.S. Kahreh, "Explanatory study towards analysis the relationship between total quality management and knowledge management", Procedia - Social and Behavioral Sciences, vol. 109 , pp. $600-604,2014$.

[6] N. Suwandej, "Factors Influencing Total Quality Management", Procedia - Social and Behavioral Sciences, vol. 197, pp. 2215-2222, 2015.

[7] A. Cetindere, C. Duran, M.S. Yetisen, "The effects of total quality management on the business performance: An application in the province of Kütahya", Procedia Economics and Finance, vol. 23, pp. $1376-1382,2015$.
[8] A.V. Todorut, "The need of Total Quality Management in higher education", Procedia - Social and Behavioral Sciences, vol. 83, pp. 1105 $-1110,2015$

[9] O.M. Rezeanu, "The implementation of quality management in higher education", Procedia Social and Behavioral Sciences, vol. 15, pp. 10461050, 2011.

[10] S. Srima, P. Wannapiroon, and P. Nilsook, "Design of total quality management information system (TQMIS) for model school on best practice", Procedia - Social and Behavioral Sciences, vol. 174, pp. 2160 $-2165,2015$.

[11] L.E.D. Crawford and P. Shutler, "Total quality management in education: problems and issues for the classroom teacher", International Journal of Education Management, vol. 13, no. 2. 1999. 